\title{
МЕЖДУ ВОЙНОЙ И РЕВОЛЮЦИЕЙ. СТАТЬИ Ф.А. СТЕПУНА В ГАЗЕТЕ «АРМИЯ И ФЛОТ СВОБОДНОЙ РОССИИ"
} Аннотация. Статья содержит краткий анализ статей Ф.А. Степуна, опубликованных им летом
1917 года в газете «Армия и флот Свободной России» и текст соответствующих статей. Несмотря
на повышенный интерес к личности философа, указанный период его жизн не отражен в научных
исследованиях. Тем не менее, текст статей, не вошедших в сборники его произведений, представля-
ется важным для формирования полного представления о личности философа.

Ключевъе слова: философия, история философии, Степун, война, революция, мир, Россия, политика, 1917, Русский инвалид.

Биография Федора Августовича, как и большинства его современников, - пример сложной судьбы человека, на долю которого выпало пережить редчайшую совокупность социальных катаклизмов. Ученик В. Виндельбанда, основателя баденской школы неокантианства, участник боевых действий Первой мировой, руководитель Политического отделения Военного кабинета, крестьянин, театральный деятель, эмигрант, немецкий профессор-русофил - таковы основные этапы биографии Степуна.

Исследуемый период (лето 1917 г.) - этап межреволюционного состояния страны - активной участницы Первой мировой войны. Написанные в это время статьи не переиздавались более, однако при изучении атмосферы, в которой проходило формирование историко-философских взглядов Степуна, представляют определённый интерес. Текст передает невероятную напряженность духа тех, кто пытался осмыслить происходящее, найти рациональное звено в окружающем их хаосе. Но позже, в «Мыслях о России» Степун назовет этот период временем легкочувствия и легкомыслия, когда всем не хватило мужества «громко сказать себе и другим, что кощунственно звать умирать за социальную корысть земли и воли, когда человеку, чтобы быть похороненным, нужна только сажень земли, что безнравственно офицерской доблести сгибать спину перед солдатским шкурничеством и горлодерством, что ... проповедь ... самоопределения народов и меншинств вредна»1. Статьи были опубликованы Степуном в период его работы в качестве руководителя политического отделения военного кабинета, когда в отсутствие всякого прямого руководства (Керенский «забывал» о существовании Политического отделения), «замполит» Степун видел основной своей задачей организацию культурно-просветительской работы в армии. Настрой предложенных ниже статей, внешне более-менее оптимистический, по сути не скрывает тот «грешный дух уныния ${ }^{2}$, который владел Степуном в предчувствии неминуемой неудачи готовящегося наступления. Вынужденный на страницах «Армии и флота свободной России» защищать оборонческую линию Временного правительства, Федор Августович понимал, что без скорейшего «замирения» армия будет правительством потеряна и перейдет на сторону большевиков. «Причину всего, что случилось с Россией, позже в своих мемуарах напишет он, - надо искать в том, что народное понимание революции как миротворческой силы,... не разделялась ни одним из политических лагерей, кроме большевиков» ${ }^{3}$.

Тема большевизма и большевиков - отныне

\footnotetext{
1 Степун Ф.А. Жизнь и творчество. Избранные сочинения / Федор Августович Степун; вступ. статья, составление и комментарии В.К. Кантора. М.: Астрель, 2009. 807, [9] с. С. 265.

2 Степун Ф.А. Бывшее и несбывшееся / Послесл. Р. Гергеля. Изд. 2-ое, испр. СПб.: Алтейя, 2000. 651 с. С. 374.

3 Там же. С. 378.
} 
основная проблема для Степуна, болевая точка которой - неизбежность их прихода к власти. Неизбежность эта основывается на базовой антиномии русского характера - «нигилизм / апокалиптика» в терминах Н. Бердяева или «смутной тоске по запредельному», как называл эту черту Степун.

Кант утверждал, что невозможно представить историю без плана, который имеет своей целью реализацию человеческой сущности. Эта цель не может быть достигнута отдельным индивидуумом, но только человеческим родом в целом, этим-то и задается необходимость истории. Если исторический деятель, как бы значителен и могуществен он не был, воображает, что поступает свободно и в соответствии со своими собственными интересами, для Канта это означает лишь то, что любая историческая личность не больше, чем орудие в руках природы, которая реализует свой собственный план, с последствиями значительно более далекими, нежели цели какой-то отдельной личности. Неокантианец Степун, следуя этой логике, считает, что большевики - это те, кто сумел подчинить своим интересам большевизм русской души, «удержаться за пылающую гриву».

Сопоставление текста газетных статей и того, что было написано Степуном позже, приводит к мысли о том, что сознание многих в этот период российской истории, в том числе и самого Степуна, имело превращенную форму. Оно было неадекватным по причине того, что объективные процессы реальности отчуждены от субъекта. Но если сам Степун понимал это, то большинство занималось материализацией этой объективной кажимости. Двойственное сознание особенно характерно для огромной массы простых людей. Оказавшись в Петрограде в составе армейской делегации, Степун не может отделаться от ощущения, что Петроград 1917 г. - не прилив, как он ожидал, а отлив исторического бытия. Ощущение иллюзорности проходило лишь по возвращении к месту дислокации армейских частей: там Степун вновь ощущает собственную адекватность происходящему, чувствует себя самим собой.

Тема войны - первая, но не главная в представленных статьях, она вторична по отношению к теме революции. Вопрос о месте войны в ряду цивилизационных явлений и ее роли в истории, о сущности войны как общественном явлении, о возможностях и условиях устранения войны из жизни общества, Степуном не затрагивается. Ему интереснее частные аспекты этого феномена политической истории общества: война как насилие над душой и волей русского солдата, война как источник интернационализма (солдат-немец, враг, ближе, чем те, кто остался в тылу грабить Россию) ${ }^{4}$, война как потенциальный противовес революции. При условии сохранения боеспособности армии и более-менее удачного ведения боевых действий, существовала вероятность «выпустить пар» социального напряжения и ограничиться Февралём. (Однако трудно себе представить успешной ту армию, где приказы командования не выполняются, а дебатируются сначала и часто игнорируются, где носителем образа врага может оказаться не противник, а собственное офицерство. Все это результат деятельности Советов депутатов, в частности т.н. «Приказа №1»).

Революция - психология массы, война - совесть толпы. И война, и революция - социальные катастрофы, влекущие за собой многочисленные потери. И если война - потери человеческие и экономические, возможно, в случае поражения, потеря независимости, то революция - период упадка морали, ценности жизни, неизбежное разрушение и утрата как части материального, так и духовного богатства нации. Её выход за пределы правового поля влечет за собой шаткость её собственной легитимности, что, в свою очередь, провоцирует новый революционный взрыв. Соглашаясь с распространённым мнением о том, что революция - это «момент истины», трудно отделаться от ощущения, что война - «меньшее зло» для нации в сравнении с нею. Как писал сам Степун: «с нежностью вспоминая войну, которую так ненавидел, и со стыдом революцию, которую приветствовал» .

\footnotetext{
4 См.: статью «Война и революция» ниже.

5 Степун Ф.А. Жизнь и творчество. Избранные сочинения / Федор Августович Степун; вступ. статья, составление и комментарии В.К. Кантора. М.: Астрель, 2009. 807, [9] с. С. 269.
} 
№ $143-21$ июня 191

\section{НАСТУПЛЕНИЕ НАЧАЛОСЬ}

Итак наступление началось. Каждый, кто эти годы войны изжил в первой линии фронта, кто революцию и послереволюционное время был также на фронте, - знает, - как трудно далось это начало наступления, как трудно оно должно было даться и какая сказалась в нем нравственная мощь русского народа, какая победа над собой.

Подлинный русский народ, а потому и солдат в глубине своего сердца никогда не принимал войны. Война почти каждым солдатом переживалась как насилие над его душою и волей. Потому, когда окопы услышали слово «свобода», они сразу же своим русским сердцем и своим демократическим инстинктом связали его со словом мир, и уже данную свободу решительно отказывались понимать без мира, который должен наступить же вообще когда-нибудь, а непременно завтра.

Какие же должны были быть сделаны нравственные усилия, чтобы стать этой, как будто уже осуществленной в свободе мечте о мире, перейти к мысли о необходимости продолжения войны за мир. Свершить этот теоретический переход означало ведь для каждого ни больше ни меньше, как переступить в своем сознании через свой собственный труп.

И вот, офицеры и солдаты наступающих частей это сделали.

Честь и слава оставшимся в живых, вечная память павшим.

Я видел сам, когда в конце прошлого месяца, в качестве делегата от 7 армии, в Исполнительный Комитет Совета Рабочих и Солдатских Депутатов, подымал мой 7 Сибирский корпус с места его тылового расположения в поход к первой линии, как мучительно переживалось солдатской и офицерской средой эта сказавшаяся тогда и сказавшаяся сейчас возможность перехода в наступление.

Солдатская масса на дивизионных и полковых митингах производила тогда впечатление тяжело больного человека. Днем она в своем целом думала правильно и разумно понимала, что революционный клич русского народа о мире всего мира наталкивается в Германии на зажатые уши, и что потому нужно, чтобы гром боя заставил бы руки германского империализма оторваться от народных ушей, дабы расслышали эти уши священную весть о мире в свисте бомб и шрапнелей.
Но когда падала ночь, температура митинговой толпы начинала повышаться, начинался больной бред, - бред, вызываемый у одних страхом за свою жизнь, у других мечтою о возвращении домой, у третьих громадной усталостью, у четвертых склонностью к демагогии, у пятых немецким золотом, щедро оплачивающим всякую провокацию, и все это, ища себе идейной формы и нравственного оправдания начинало выкрикивать непродуманные и вредные лозунги большевизма.

Корень же болезни заключался быть может в том, что в ночной час испытания душевных сил и некоторые здоровые элементы армии, готовые днем идти и исполнять свой долг, начинали иной раз испытывать темную радость, что их не пускаюm, что им не дают пулеметов, что им грозят, в случае если бы они пошли, открыть по ним братоубийственный огонь, что их ставят в условия, при которых невозможно идти.

Этот поворот мысли в сущности так понятен. Я помню себя, помню, как на батарею ложится трехсотый тяжелый снаряд. Я знаю, что я здесь нужен, но я так устал от картины смерти вокруг, что все-таки тайно рад, когда 301 снаряд ломает прицельное приспособление и командир батареи дает мне приказание отвести взвод в тыл.

Так жила последнее время русская армия в постоянной борьбе между революционным долгом и корыстным соблазном.

Я запомнил и никогда не забуду виденные мною на фронте картины.

Ночь светлая, лунная. По небу спешно пробегают последние тучи отгремевшей грозы, в громах и зарницах которой полковой митинг час тому назад, решал вопрос о выступлении на позицию, и на две трети своего состава решал идти.

На холме за деревней блестит в лунном свете медь труб, звучит марсельеза, вокруг оркестра развеваются красные знамена. Говорят последние перед выступлением речи, прерываемы громким ура. Люди целуют друг друга, у многих слёзы в глазах. Энтузиазм искренен и глубок: в своем порыве он тщательно и почти сознательно бережет, после тяжелой внутренней борьбы принятое всеми выступающими свободное решение пойти, и, если Бог не спасет, - умереть за свободу, революцию и Россию.

Идет кто? Идут прежде всего сознательные элементы революционной армии, - квалифицированные специалисты, стоящие на точке зрения большинства революционной демократии. К ним примыкают все крепкие духом и светлые 
совестью простые солдаты крестьяне и много раз раненые старые воины георгиевские кавалеры, которым не страшен бой, потому что они хорошо знают его в лицо, и которым страшна гибель России, за которую они уже не раз проливали свою кровь. Тут же вечные русские идеалисты старозаветные интеллигенты в лице офицеров запаса, и наконец лучшие элементы несчастного сейчас кадрового офицерства, которое, еще не научившись жить в новой России, искренне готово за нее умереть.

Вот основные элементы того пестрого психологического блока, который многообразный но единый, и сейчас, в минуту начавшегося наступления, подлинно революционный, одержавший громадную нравственную победу над бессознательными и корыстными элементами как в армии, так и внутри сердец своих собственных сочленов, - требует от всей России всемерной, безоговорочной поддержки, восторженного, бережного и любовного к себе отношения.

Пусть те люди, что еще сомневаются, нужно ли это наступление или нет, сохранят это сомнение глубоко в своем сердце, пусть замкнут свое сердце на ключ, а ключ выбросят в море того общенародного чувства горячей признательности и благоговейной благодарности к тем героям, что жизнью своею отстаивают свободу, революцию и Россию.

Пусть ни одно слово сомнения не дойдет сейчас до слуха того солдата крестьянина, который накануне своего спасения в добытой земле, готовится лечь в сырую землю.

Пусть ни одно слово сомнения не оскорбит того солдата социалиста, который, умирая под проволокой верит, что он умирает за святыню своих идеалов.

Пусть никто не посмеет сейчас сказать кадровому офицеру, который впереди батальона идет на верную смерть, что его порывом к бою владеет психология отжившего царизма.

Все это сомнения, мысли и недомыслия должны сейчас смолкнуть. Вся Россия должна сейчас как один человек поддерживать свою республиканскую революционную армию и загореться творческим порывом к миру, который требует, как своей жертвы вечерней, этого неизбежного наступления.

\section{Фёдор Степун}

katerina.loginova@list.ru № 152.- 1 июля 1917.

\section{ВОЙНА И РЕВОЛЮЦИЯ}

Когда я в первых числах апреля приехал в Петроград в составе армейской делегации и познакомился со всем строем работы и мысли Совета Рабочих и Солдатских депутатов, я сразу, вместе с целым рядом товарищей по делегации почувствовал, что революционный Петроград воспринимает нас, представителей армии, не вполне так, как мы сами ощущаем себя. Я сразу почувствовал, что Совет Рабочих и Солдатских депутатов до некоторой степени как бы боится армии как некоего сфинкса, на которого быть может не совсем и не во всем можно до конца положиться. Вдумываясь в эти побеги и ответвления главной мысли Петроградского Совета, который сразу же определённо и безоговорочно заявил о том, что сила и спасение русской революции в полном революционном единении рабочего и солдата, я ясно расслышал тревогу революционной демократии, как бы война не убила русской революции.

Что расслышанная нами тогда тревога была не галлюцинацией, а вполне правильно уловленной нами нотой во всем строе советских мыслей и чувств, доказала произнесенная в момент начавшегося наступления речь министра труда Скобелева, в которой он откровенно признался, «что во многих из нас жила тревога, как бы война не сожрала революции».

На всероссийском съезде, который так остро волновался вопросом о наступлении, эта тревога победы войны над революцией снова подняла свою голову, и надо сказать, <...> кругах. Меньшевики и C.P. не стоящие на крайнем левом фланге своих партий говорили о том, что удачное наступление, раздуваемое буржуазной прессой и не оспариваемое социалистическим большинством, ибо нравственно трудно оспаривать людей, которые согласно своему внутреннему чувству идут умирать за свободу и революцию, может в связи с бессознательностью и инстинктивным национализмом широких слоев общества породить вполне определённый революционно-воинственный шовинизм, в корне враждебный чистой идее русской революции.

Слушая такие речи, я их никогда не понимал. Они всегда дышали для меня почти тою же отвлеченностью, как речи лучших из 
большевиков. Говорит человек и как будто все складно, но смотришь на него и видишь, что у него перед глазами совершенно нет действительности. Не встает перед ним во время речи ни одной русской картины, не видит он ни сохи на пашне, ни галки на заборе, ни часового впереди проволоки, ни раненого в лазарете, который когда все засыпают, принюхивается к себе под одеялом: началось ли заражение, или нет. Вместо всего этого, платформенные колесики, логические передаточные ремни, шныряющие взад и вперед челноки рассудочных доказательств, одним словом целый механизм отвлеченности, монотонно стучащий в Торричелевой пустоте пустынного сознания.

Кто действительно вовремя войны был на войне, был в первой линии, и не молча ходил по окопам, но искренне и серьёзно беседовал с солдатами, что не стали для него товарищами только после революции, но были таковыми и до нее, кто смотрел на окопную жизнь и в душу солдатскую не бельмами казенного патриотизма и шовинистической лжи, которыми дышала решительно вся пресса и улица, но живым и пытливым человеческим глазом, тот думается мне, раз навсегда понял, что нет у войны более заклятого врага, чем русский солдат, и что зажечь в его душе огонь какого-бы то ни было шовинизма, решительно невыполнимая задача.

Каждый разведчик, в минуту, когда он крался навстречу врагу-немцу, чтобы «снять» его, чувствовал, что этот «враг» чем-то и в чем-то много ближе ему всех тех, оставшихся в тылу грабить Россию, русских купцов, поставщиков и спекулирующих фабрикантов что неустанно трубят о чудо богатырях и геройском наступлении на Берлин.

В сущности это так понятно: конечно двое приговоренных к смерти внутренне ближе друг к другу, чем каждый из приговоренных к своему судье и палачу.

Я глубоко уверен, что в длинные зимние ночи в окопах, в секретах, в заставах из русских солдат самых бессознательных, самых темных, ковались самые крепкие, самые стойкие защитники подлинного интернационализма, которых в их выстраданном чувстве правды и лжи в жизни народов никак не обойти и ничем не одурачить.

Действительность этой ковки обеспечена еще и тем, что молот войны бил по сердцу русского солдата и офицера в то время, как сердце это плавилось в огне предельного негодования к тому старому строю и правительству, что невозможное сумело сделать возможным: заставило себя ненавидеть больше войны.

Я помню как мы брали Карпаты, как пехота голыми ладонями грызла немецкую проволоку, как штабом дивизии было назначено расследование, по какой цели и с каким результатом наша батарея выпустила за день 10 снарядов, и как, несмотря на все это, мы в продолжении лютой зимы упорно двигались вперед, роя из ночи в ночь в тылу каждого полка сотни могил и ставя на них одинокие белые кресты, и как мы потом весною без оглядки на оставленных товарищей мимо разных могил неслись к своим собственным могилам, к Сапу, к Любачувке, к Панской горе и т. д.

После всех этих переживаний, показавших всем, что так дальше жить нельзя, перед каждым сознательным солдатом и офицером встала, и не показала его до мартовских дней великая проблема последних лет, проблема отношения войны и революции.

Решили ее по-разному. Одни хотели идти к революции через победоносную войну, другие через поражение, третьи через революцию к победоносной войне.

Жизнь пошла своим путем и дала вполне определенный ответ.

Она повела Россию через революцию невероятного масштаба - к войне с войной к борьбе за мир.

Война в старом смысле этого слова, война как дело рук империализма, война как функция национализма, война как шовинистический угар и лжепатриотизм, - убита тем, что революция осуществила себя во время войны. В сущности, война - труп у ног революции; этот труп не воскреснет. За это ручается каждый русский солдат, подлинный друг, подлинного интернационализма.

И потому что война труп, и потому что солдат страж Интернационала, мы должны откинуть раз навсегда всякую боязнь, что война сожрет революцию, мы должны понять, что это выдумка, которая совершенно неосуществима в атмосфере той реальности, которую представляет собой душа солдатской массы.

Мы должны раз навсегда понять,что военные действия, которые творятся на фронте, что то наступление, которое уже сказалось и бесспорно будет и дальше сказываться на сговорчивости Германии, суть по всему историческому и психологическому существу и значению своему не действия убитой войны, но действия живой революции, 
которая крепнет, расширяется и окапывается на своих передовых позициях.

Кто действительно творчески приемлет революцию, тот должен принять ее во всей ее сложности. Ея сложность в том, что она свершилась во время войны и неразъединимо переплелась с ее наследием, которое нельзя игнорировать, которое нужно осилить. Рожденная в крови под гром боя, русская революция и для своей защиты требует крови и боя. В этом ее трагедия, в этом ее пафос.

Армии труднее всех было встать на эту точку зрения, ибо против неоспоримой правды этой точки зрения в армии говорил самый сильный в человеке инстинкт - инстинкт жизни и самосохранения. После тяжелой борьбы армия встала на эту точку зрения, и мы ей должны поверить, ибо свободных людей на смертный подвиг может вести только правда.

Фёдор Степун

№ 1556 июля 1917

\section{БОЛЬШЕВИЗМ И КОНТРРЕВОЛЮЦИЯ}

Каждый раз, когда вожди социалистического большинства выступали с критикой большевиковленинцев, устно ли, или в печати, они тщательно оговаривались, что говорят не об идейном большевизме, с которым они не согласны, но который также уважают как всякое честное мнение открытого противника, но лишь о большевиках, как о людях определённого строя мыслей и чувств, глубоко искажающего природу теоретических лозунгов идейного большевизма.

Эти оговорки были в свое время конечно необходимы, в них звучала глубокая социалистическая вера в созидающую силу безусловно свободного слова, глубокое уважение к отдельным вождям большевизма, как к некогда видным фигурам русского социалистического движения, и наконец, тот энтузиазм доверия к течению революции, который так естественен, и даже больше, так обязателен для каждого органического революционера.

Но чем дальше шла революция, тем труднее и опаснее становилось делать эту оговорку. Термин идейного большевизма, за отсутствием всякой идеи в том, что делалось под знаком большевизма, все в большей и в большей степени переставало покрывать собою какое бы то ни было содержание текущей действительности. Свой смысл он все более и более начинал обретать лишь в отношении к прошлому или будущему, в отношении к памяти о бывших большевиках, в надежде на то, что большевики настоящего времени когда-нибудь да опомнятся.

Ныне для каждого, кто знает вес словам вообще, а особенно вес слова ответственного деятеля в эпоху революции, такие оговорки становятся не только опасными, но прямо таки преступными и соблазняющими.

Под знаком большевизма последние дни происходили вещи, которые вся революционная демократия, без малейшего колебания, заклеймила как предательство революции, как кровавый удар в спину нашей, с красными знамёнами, наступающей армии, как измену России и всему трудовому народу.

Эффект деятельности большевиков последние дни абсолютно совпал с эффектом деятельности прежней той стаи царских стервятников, что уже десятки лет кружат над больною Россией, и с эффектом деятельности немецких провокаторов и шпионов.

Раз это так (а в том, что так никто сомневаться не только не может, но просто не смеет), то слова «идейный большевизм» должны быть немедленно изъяты из употребления.

Революция - эпоха волевых устремлений, эпоха стремительной действенности. Слова и лозунги, выдвигаемые революцией, должны потому характеризовать явления, о которых они говорят c их действенной стороны. Раз в результате деятельности идейных большевиков получается контрреволюционное движение, надо немедленно начать называть всех большевиков контрреволюционерами, а термин «идейного большевизма» на время революции сдать в архив, дабы он никого не вводил в заблуждение, и дабы не трепалось по грязи прекрасное слово «идея».

От правильного наименования вещей очень многое зависит. Борьба с идейными большевиками, называемыми, согласно их теперешнему облику, контрреволюционерами, гораздо понятнее для широких масс, чем борьба с ними, как с контрреволюционерами, называемыми по старой традиции «идейными большевиками».

Большевикам, если они не те горбатые, которых исправит могила, давно пора понять, что в плане своего действенного проявления, они или сконцентрированный яд, растворяющийся в мутной воде бессознательной уличной толпы, или сами мутная вода, в которой стремится раствориться сконцентрированный яд немецкого 
шпионажа, или наконец, что вероятнее всего, и то и другое вместе, т.е. обманутые обманщики, революционеры в когтях реакции, реакционеры в масках революции.

Поняв это, они должны испугаться, и те из них, которые еще чисты, для которых термин идейного большевизма еще не пустой звук, должны принять все меры к тому, чтобы вырвать социалистический идеал большевизма, из когтей реакции и сорвать с контрреволюции маску социалистической революционности.

Сделать это в плоскости революционной практики - очевидно нельзя, ибо путь большевизма, как показали последние дни, обречен в этой плоскости на полное слияние с воздвигающейся контрреволюцией.

Вывод потому ясен, дабы отмежеваться от подымающей свою змеиную голову шипящей реакции, идейный большевизм, как таковой, должен отказаться от проведения в жизнь своих идеалов, в чем для него не должно было бы быть ничего неприемлемого или парадоксального так как таковой отказ в сущности предуказан основами научного марксизма, безусловными поклонниками которого слыли когда то вожди нынешних большевиков.

Грань между большевиками и контрреволюционерами должна была бы в таком случае определиться так: идейный большевик, это большевик, подчиняющий свою революционную практику советскому большинству, над перерождением точки зрения которого он лишь теоретически работает, но не претворяющий своей теории немедленно в жизнь, дабы не слить это претворение с «творчеством» контрреволюции, контрреволюционер, - это тот же большевик но не подчиняющий своей революционной практики воле Совета, требующий немедленного проведения в жизнь своих лозунгов, и тем самым сливающий свою революционную практику с практикой контрреволюции.

О первых можно, пока что, забыть, ибо не время действенной революции помнить о сугубых теоретиках и бездейственных Гамлетах, о вторых необходимо неустанно помнить, ибо если забыть о них, то от русской революции может остаться одно только воспоминание.

\section{ТВЕРДАЯ ПОЗИЦИЯ}

Для восстановления порядка в Петрограде, для закрепления главных позиций революции, которые сознательные и бессознательные враги народа и свободы стали как будто уже обходить как с левого, так и с правого фланга, Временным Правительством в полном согласии с Советом рабочих, Солдатских и Крестьянских Депутатов были вызваны с фронта верные революции войска.

6 июля поздно вечером представители этих войск были приглашены в Таврический Дворец на совместное заседание Исполнительных Комитетов Совета Раб., Солд., и Крест. Депутатов, где они беседовали с министром Скобелевым, председателями Советов - товарищами Чхеидзе и Авксентьевым, где и сами высказывались о неотложных задачах, стоящих перед революцией, и о том, как они сами понимают смысл своего прибытия в Петроград.

Слушая эти речи, нельзя было не удивляться политической зрелости армии. Нельзя было не радоваться тому свежему дыханию революции, что она принесла с собой, нельзя было не чувствовать, что те убеждения, которые куются человеком в постоянном созерцании наступающей на него лично смерти, исполнены крепости и иной серьёзности, чем те, что слагаются в мозгу многих Петроградских статистов революции, в исключительной атмосфере газет, собраний и митингов.

Петроград может быть совершенно уверен, что пришедшая с фронта армия - это подлинный цвет русской революции. Армия не подастся ни в право, ни в лево. Ея позиция, говоря образами одного из ее ораторов, по-солдатски отчетлива и крепка. Имущество русской революции сдано по описи часовым. Часовые, Временное Правительство и Совет Раб., Солд. и Крест. Деп. Часовой не смеет под страхом смерти никого допустить к охраняемому имуществу без разводящего. Разводящий - Учредительное Собрание, но и только оно. Если часовой, после сделанного предупреждения видит, что ему и охраняемому имуществу грозит опасность, он свистком вызывает патруль.

Пришедшие с фронта части - патруль, вызванный часовыми русской революции в предупреждение того, что бы богатства созидающейся России не были бы расхищены безответственными людыми, забывшими свой долг перед революцией и Россией. 
Люди, которые так ясно ставят вопросы и так ясно отвечают на них, не могут быть смущены никакой пропагандой.

Пропаганда обрушится на прибывшие с фронта части с двух сторон. Штурмовать подлинно революционный дух армии попытаются как те, что думали зайти в тыл революции слева, так и те, что пытались обойти ее правый фланг.

Большевики пытаются убедить пришедшие части в том, что их обманывают, говоря, что они защищают революцию, убедить в том, что в сущности армия, сама того не замечая, уже давно во власти контрреволюции, которая заново раздувает империалистическую войну в надежде на то, что требования войны сожрут задачи революции.

Товарищам большевикам, пришедшие с фронта солдаты скажут, что во первых, фронтовиков обмануть невозможно, ибо они сами думают обо всем не хуже большевиков; что во вторых, они не видят в наступлении контрреволюции, хотя бы уже по одному тому, что слишком хорошо знают обратное, знают как часто большевистская проповедь братания и пассивной обороны отдавала части русской армии в полное распоряжение германского генерального штаба, знают, что с большевистскою проповедью всюду в армии выступают на ряду с немногими идейными большевиками, прежде всего жандармы, и замаливающие свои старые грехи офицеры держиморды; и в третьих, наконец, армия скажет большевикам, что боязнь, как бы война не сожрала революции, для армии пустая боязнь.

Спор между войной и революцией может решиться только в солдатских сердцах. Но сердца эти давно решили этот спор, решили его в пользу революции тем, что осуществили её во время войны. Война в случайном все же образе немецкого солдата три года лютым врагом стояла перед русским солдатом. Революция нанесла этому врагу смертельный удар. Как же можно думать, что солдатская масса пойдет с врагом своим, с войной, против спасительницы своей, против революции.

Это не мысль, это бессмыслица. Если солдатская масса наступает, так только потому, что она из глубины сердец своих знает, что противонародная война покойник, что жива только народная революция, и что все военные действия фронта суть действия революции, которая в эпоху мировой войны не может защищать себя иначе, как на поле брани с оружием в руках.
Товарищам большевикам армия скажет «товарищи, кому другому, но отнюдь не вам бояться, как бы мы не попались в сети контрреволюции; посмотрите на себя, посмотрите, как под маской ваших лозунгов творит свое темное дело голая контрреволюция. Посмотрите на себя, задумайтесь, устыдитесь, отойдите в сторону и знайте, что мы наших красных знамен, не отдадим на прокат черной силе, как вы уступаете ей ваши партийные лозунги.

Кроме большевиков и тех, что ходят под маской их, к прибывшим частям армии подойдут и другие люди с другими речами. Они прикинутся простым и встревоженным русским людом, подлинными печальниками земли русской, стражами справедливости и выразителями голоса всей России. Они будут льстить армии как заступнице и спасительнице, они будут шептать солдатам фронтовикам, что давно пора армии, подлинному хозяину России взять революцию в свои руки, что Петроград ее губит, что тут много немецких шпионов и «жидовских» денег, что революционный гарнизон Петрограда - сплошь тыловики и дезертиры, которых давно пора заменить частями действующей армии, доблестными защитниками России и революции.

Этим людям на их льстивые речи фронтовики определённо ответят: «отыди сатана, не соблазняй нас, и на нас не надейся» Мы спасали Россию, как могли, но вместе с нами ее спасали и рабочие Петрограда и революционный Петроградский гарнизон; мы не позволим Революции идти мимо наших требований, но мы и не хотим прибрать ее к нашим рукам; мы пришли к тылу с твердым требованием твердой революционной власти, но мы отнюдь не мечтаем о диктатуре фронта.

Петроградскому гарнизону и Петроградским рабочим, поскольку они с Временным Правительством и с большинством Совета рабоч., Солд. и Крест. Деп., мы отнюдь не противополагаем себя. Мы плоть от плоти и кость от кости организованной в Петрограде революционной демократии. В качестве таковой мы опечаленные пришли сюда на поддержку Временному Правительству, и уйдем отсюда при первой возможности и чем скорее, тем лучше. Строить же на наших окопных страданиях свою революционную карьеру патентованных охранителей Петрограда было бы ниже нашего достоинства, противоречило бы нашей революционной совести. 
Вот вкратце те соблазны, что грозят представителям действующей армии, прибывшим в Петроград. Мы убеждены, что она налево ответит: «не беспокойтесь за нашу наивность, нас никто не обойдет, и никто не одурачит», - направо - «Не надейтесь на нашу силу, мы слишком сильны, чтобы злоупотреблять ею».

Федор Степун

№ 16228 июля 1917

\section{О ПОЛИТИЧЕСКОМ ВОСПИТАНИИ АРМИИ}

Своим переходом в наступление армия обнаружила, как я уже вчера писал, громадный инстинкт истины, подлинное разумение революционных, социалистических, государственных и национальных задач России.

Этот инстинкт разумения истины хочет и должен стать в армии подлинным знанием истины, постоянною политической сознательностью. На фронте невероятно сильна тоска по книге, по газете, по всяким экономическим и политическим, правовым и историческим сведениям и разъяснениям, также и по художественной литературе.

Многие приезжающие с фронта и целый ряд письменных заявлений армии согласно свидетельствуют о том, что в армии настала пора некоторого утомления от митингов и споров. И оно понятно. Митинг есть всегда форма воздействия нескольких ораторов и политических деятелей на толпу. Эти митинги сыграли в жизни армии, и будут еще, конечно, продолжать играть громадную роль, направляя волю масс по определённым политическим руслам.

Но кроме воздействия на себя, и прежде всего на свою бессознательность, солдатская масса хочет еще, и хочет все настойчивее своего сознательного действия, хочет возможности критики над словами ораторов, хочет полной своей распорядительности в области тех знаний, которые обнаруживает приезжий ответственный агитатор или какой-нибудь старый партийный работник из докторов или вольноопределяющихся. На фронте эта жажда критики особенно остра, и остра потому, что от решения теоретического вопроса: правильно он говорит или нет, зависит решение гораздо более трудное нравственного вопроса: идти на позицию или нет, идти в наступление или не идти.
Очень много говоря за время войны на фронтовых митингах и очень много слушая других, я сам был не раз свидетелем того, как народилась в солдатской массе жажда критики, жажды по совести решать вопрос «дело он говорит или брешет», и как в результате невозможности за отсутствием всякого знания разрешения этого вопроса, раздавались бессознательные голоса: «а что он за человек, арестовать его, да и все».

Это «арестовать» означало в целом ряде случаев лишь жажду критики, которая за невозможностью осуществиться по отношению к смыслу слова оратора, осуществлялась по отношению к нему самому, как к более уловимой сущности.

Я знаю и более положительные формы проявления той громадной жажды знания на фронте, о которой говорю. Помню, как я с комиссаром седьмой армии обходил окопы, и как мы в каждой роте говорили по самым общим вопросам политического и экономического строительства России. Я помню правый фланг одного из полков 13 дивизии. Дело было под вечер, немцы в 70 шагах, все время свистят пули. Мы сидим в окопе, вокруг нас густо стеснились солдаты и офицеры, весь окоп буквально набит людьми, некуда яблоку упасть. Но аудитория растет и растет, и те, которым нельзя больше поместиться в окопе, которым нельзя протиснуться к нам по окопу, несмотря на предупреждение ротного: «по верху не ходи», - бегут по верху, ложатся наверху, на животе у задней стенки окопа, под толью брустверного гребешка и жадно слушают рассказ об учредительном собрании, о том, почему Милюков ушел, о земле, о воле и восьмичасовом рабочем дне.

Я помню еще и другой полк другой дивизии, где очень болезненно и бурно протекало разрешение вопроса о том, исполнять ли боевое приказание или нет. Две трети решили исполнять, одна треть решила не исполнять. На митинге обе части расстались непримиримыми врагами.

Мы с комиссаром обещали приехать проводить выступающие на позицию роты. Приухадя; до часа, назначенного для выступления оставалось еще минут 40. Солдаты попросили рассказать чтонибудь толком.

Я с автомобиля начал читать солдатскую лекцию, кажется о социализме. Из ближайших халуп к отходящим стали подтягиваться «забастовщики»; обе враждующие части полка слушали меня одинаково внимательно. Кончилось тем, что 
«забастовщики» провожали отходящие роты и желали им доброго пути. Те благодарили и звали подтягиваться. Митинг разъединил, лекция соединила. Это весьма знаменательный факт, над которым, памятуя, что в единении сила, весьма и весьма нужно задуматься.

В заключение мне вспоминается еще один характерный разговор с очень умным пулеметчиков, который во главе всей пулеметной команды отказался идти на позицию.

Он мотивировал свой отказ очень ловко той сознательностью, которая «по настоящим временам» требуется от каждого солдата «даже и самим начальством», не говоря уже о Петроградском Совете.

Для того же, чтобы сознательно пойти на позицию или в наступление, ему необходимо решить вопрос, нужно ли еще продолжение войны, допустимо ли наступление. Но решать этот вопрос на позиции он никоим образом не может за отсутствием книг, газет, лекций. Из всего этого следовало требование пулеметчиков отойти до Киева, откуда они после своего политического самоопределения согласны, если они признают наступление на благо для народной России, идти все, как один человек, хотя бы на верную гибель.

Спорить с этим пулеметчиком мне было очень трудно. Доказывать ему, что он должен идти в бой, не понимая зачем для России нужно наступление, не приходилось. Ходатайствовать перед комиссаром и начальством об отмене боевого приказания и отвозе пулеметчиков в тыл для политического самоопределения - приходилось еще меньше.

Оставалось лишь поговорить с ним на тему о том, как сделать так, чтобы политическое самоопределение могло бы осуществляться солдатами в своих окопах.

Тема эта громадная. Над ней надо серьезно задуматься всем, кто стоит на страже народных интересов. Надо чтобы пулеметчики не требовали их отправки в Киев; надо двинуть Киев, Москву и Петроград в окопы.

\section{Федор Степун}

№ 16518 июля 1917

\section{КОАЛИЦИОННОЕ ПРАВИТЕЛЬСТВО}

После событий на фронте, главным центром общественного внимания является сейчас об- разование коалиционного кабинета. Необходимость такого кабинета ясно признана всеми. За последние две недели дело русской свободы, самой независимости и национальной самостоятельности русского государства получило два таких удара, которые делают положение чрезвычайно тревожным. С одной стороны предательские выступления большевизма, направленные к разрушению государственной власти, с другой же стороны трагические события на театре военных действий, паническое, ничем, строго говоря, не вызванное массовое бегство с полей сражения, с ужасающей ясностью показали, какой степени разложения достигла наша армия под влиянием изменнической агитации и ослабления внутренней организованности. А если сюда прибавить расстройство транспорта, сделавшееся прозаическим еще в печальной памяти время старого порядка, неудовлетворительное положение продовольственного вопроса, целый ряд сложных и чрезвычайно затруднительных проблем, выдвигаемых на очередь возможностью зимней кампании, то общее положение страны нельзя не признать весьма и весьма угрожающим. И нужно помнить, что речь идет здесь не о крахе той или иной политической и социальной программы, опасность грозит здесь не только политическим начинаниям чистого демократизма, не одним словом, завоеваниям революции, но самой независимости и культурной самостоятельности России. На карту поставлена судьба не социалистических и либерально-демократических реформ, не Россия социалистов и либералов, но Россия, как единое культурное целое, как великая нация, как наша общая родина. Это нельзя ни на минуту упустить из виду, чтобы не сбиться с дороги, чтобы под влиянием тех или иных сословных, кастовых, партийных и иных предвзятых точек зрения не принять ложных решений, могущих повлечь за собой внутренние распри и разлад, вплоть до нового взрыва гражданской войны.

Именно потому, что опасность угрожает всей России, всему Русскому народу, как национально-культурной единице, что для предотвращения этой опасности необходимы напряженные усилия всех классов и общественных групп без изъятия, именно поэтому необходимо правительство так конструированное, чтобы оно пользовалось бы всеобщим доверием и поддержкой, на котором сошлись бы все влиятельные группы 
населения. Из этого основного положения проистекают важные выводы для определения желательного характера будущей государственной власти. С одной стороны, должна безусловно отпасть всякая мысль о военной диктатуре и т.п. установление такой власти встретило бы сразу ожесточенное сопротивление со стороны чрезвычайно широких слоев населения, привело бы к возникновению гражданской войны и новым глубочайшим потрясениям, исход которых невозможно предвидеть. Это могло бы оказаться новой революцией, вероятным итогом которой явился бы полный распад государства. Точно так же может оказаться недостаточно сильным и правительство с чисто либеральной или исключительно социалистической программой. Такое правительство неизбежно может натолкнуться на весьма энергичную оппозицию со стороны определённых классов, которая может в сильной степени парализовать его деятельность.

Нет, лозунг «страна - отечество в опасности» с необходимостью подсказывает иное решение вопроса о перемене государственной власти. Правительство, решающее общенациональную задачу, должно быть общенациональным. Само собой понятно, что это не значит, что оно должно вовсе отказаться от социальных или политических мероприятий. Отнюдь нет. Но программа его должна быть компромиссной. Общенациональное правительство - это правительство компромисса, правительство коалиции, правительство социально-политического соглашения и союза различных классов перед угрозой национальной катастрофы. Только такое правительство может дать безусловные гарантии конечного преодоления величайших затруднений, стоящих перед страной и благополучно довести ее до Учредительного собрания.

И надо надеяться, что ближайшее будущее принесет нам создание такого правительства. Идея соглашение начинает облекаться в конкретные формы и по всей вероятности оно в конце концов состоится. Конечно, не надо закрывать глаза на те затруднения, которые могут при этом возникнуть. Ведь коалиционное министерство, которое возникнет в итоге этого соглашения, будет резко отличаться от тех, которые мы имели раньше. Там программа и тактика определялись в сильной степени внешним ходом вещей. Жизнь в значительной мере сама указывала ему линию поведения, и ему нередко приходилось идти за массой, напрягая все усилия лишь к тому, чтобы сдерживать ее порывы. Но нет никакого сомнения, что новое коалиционное министерство будет гораздо более свободным в этом отношении. А в силу этого и его печатная программа получит гораздо большее значение. Но раз выполнение программы почти гарантировано, то вполне конкретный, практический характер приобретает и процесс соглашения. Он становится реальным торгом, где заинтересованные стороны понуждаются к заключению сделок возможностью общей беды, но все же не хотят упустить своих выгод. Ближайшие дни покажут нам, состоится ли эта сделка. Если же ее не будет, то тогда ныне существующей власти придется оставить на себе же тяжкое бремя государственных забот и дальше вести страну в будущее, спасая ее от анархии, от чрезмерных притязаний отдельных классов, от предательских попыток повернуть вспять и историю. И тогда долг каждого гражданина, свободного от всяких предвзятых точек зрения, долг каждого истинного патриота будет поддержать ее, в великом подвиге.

\section{ТЯЖЕЛЫЕ ДНИ}

\section{О твердой власти}

Вряд ли история России знала более тяжелые дни, чем те, что мы только что пережили и те, что мы еще переживаем.

3 и 5 июля в Петрограде ярко пылал бунт кровавого мятежа, в то время, как на фронте гасло бледное зарево того революционного воодушевления, которое бросило в наступление полки 18 июня.

В Петрограде солдаты и матросы захватывали винтовки и пулеметы, чтобы стрелять в безоружную толпу, в то время, как солдаты на фронте предательски бросали винтовки в канавы и леса, чтобы не стрелять в вооруженных до зубов наступающих на нас немцев.

Из недр гибнувшей армии, чувствующей, что она своей гибелью губит Россию, из уст старого борца за свободу, приговоренного Николаем II к смертной казни за террор, из уст фронтового комиссара Юго-западного фронта Бориса Савинкова, раздалось требование восстановления смертной казни.

Правительство, наполовину состоящее из социалистов, пошло этому требованию навстречу, и смертная казнь, отмененная Временным прави- 
тельством первого созыва, в составе которого был только один социалист, ныне им заново введена.

Вместе с введением смертной казни осуществлены аресты большевиков, закрыты газеты «Правда» и «Окопная правда», урезана свобода слова, введена цензура.

Не то, конечно, что это сделано, ибо сделать это было совершенно необходимо, но то, что течение революции привело представителей социализма и революционной демократии к сознанию печальной необходимости таких кровавых и суровых мер, наполняет сердца наши глубокой скорбью.

Революция дошла ныне до своего трагического зенита. Третьего дня, когда я смотрел на похороны казаков, я невольно думал: Боже, до чего состарилась революция. Красные знамёна, что развевались над первыми жертвами революции, дышали бесконечною верою в ее силу и правду, в ее прямой путь и скорую победу. В них горела мечта только что рожденной революции о ее будущей жизни.

Черные же флажки на пиках, что я видел третьего дня, говорили уже о том, как бы революция не сбилась с прямого пути, говорили по крайней мере мне о раскаянии в ложных шагах, дышали уже не только верой, но и трепетной боязнью за грядущие дни. От них веяло раздумьем уже многое изжившей революции, революцией задумавшейся о грозящей ей гибели.

И тяжелее всего было то, что эта скорбь, вошедшая в души подлинных представителей революционной демократии, откровенно радовала многих, слишком многих.

«Что, дожили г.г. социалисты, доигрались? Видите плоды рук ваших? Сеяли свободу, а пожали смерть и насилие, предательство и измену. Идете по старой дороге? - цензура, аресты и смертная казнь? Стосковались по сильной власти? Ну что же, лучше поздно, чем никогда, слава Богу, что хоть сейчас поняли, что Россия дороже революции и социализма, что Циммервальд - та же охранка»...

Вот то, о чем за последние дни на всех перекрестках, потирая руки, шепотом зубоскалит крепнувшая контрреволюция, выступающая пока еще громогласно лишь под лозунгом «крепкая революционная власть», но мечтающая в сущности о крепкой власти, направленной против революции.
«Крепкая революционная власть» этот лозунг момента представляет собою ныне нечто вроде темной психической камеры, в которой встречаются, не всегда узнавая друг друга, как подлинные друзья революции, так и исконные враги ее.

Спасение революции только в железной революционной власти. Это поняли все представители революционной демократии С.P.С. и К.Д. которые ради полноты власти Временного правительства пошли - проявив глубокую мудрость, на определенное ограничение самих себя в своем отношении к Вр. Пр. Но мудрость этого акта останется незатемненной лишь в том случае, если представители революционной демократии смогут противодействовать тому, чтобы лозунг железной революционной власти не покрывал бы собою и крепкой антиреволюционной власти. Объективные признаки различия между защитниками крепкой власти слева и справа часто отступают. Надо руководиться признаками субъективными.

Те, что слева, требуют твердой революционной власти, требуют ее со скорбью в душе. Скорбь их в том, что эта власть стала уже необходимой. Свое требование они ощущают, как свой долг. Тоска их в том, чтобы их долг не превращался для них в крест. Имя, которым они требуют железной революционной власти, имя свободной России.

Те, кто справа, требуют твердой революционной власти, требуют ее с радостью в душе. Радость их в том, что эта власть наконец то признана всеми необходимой. Свое требование ее они ощущают, как свое право. Ликование их в том, что право возвратит им их потерянный рай. Имя, которым они требуют железной революционной власти, в сущности, имя <...> России.

Россия переживает тяжелые дни. В эти черные дни каждый шаг каждого ее гражданина приобретает громадный вес и исключительное значение. Всем надо стать чрезвычайно внимательными. В минуты, когда все подлинные друзья России «расширяя базис революции» объединяются вокруг правительства спасения России, им нужно тщательнее, чем когда бы то ни было всматриваться в лица и маски своих попутчиков.

Федор Степун 


\section{Список литературы:}

1. Степун Ф.А. Жизнь и творчество. Избранные сочинения / Федор Августович Степун; вступ. ст., сост. и комм. В.К. Кантора. М.: Астрель, 2009. 807, [9] с.

2. Степун Ф.А. Бывшее и несбывшееся. Изд. 2-ое, испр. СПб, 2000.

3. Степун Ф. Большевики и контрреволюция // Армия и Флот свободной России. № 155. 6 июля 1917.

4. Степун Ф. Твердая позиция // Армия и Флот свободной России. № 159. 24 июля 1917.

5. Степун Ф. О политическом воспитании в армии // Армия и Флот свободной России. № 162. 28 июля 1917.

6. Степун Ф. Коалиционное правительство // Армия и Флот свободной России. № 165-166. 16 июля 1917.

\section{References (transliteration):}

1. Stepun F.A. Zhizn' i tvorchestvo. Izbrannye sochineniya / Fedor Avgustovich Stepun; vstup. st., sost. i komm. V.K. Kantora. M.: Astrel', 2009. 807, [9] s.

2. Stepun F.A. Byvshee i nesbyvsheesya. Izd. 2-oe, ispr. SPb, 2000.

3. Stepun F. Bol'sheviki i kontrrevolyutsiya // Armiya i Flot svobodnoy Rossii. № 155. 6 iyulya 1917.

4. Stepun F. Tverdaya pozitsiya // Armiya i Flot svobodnoy Rossii. № 159. 24 iyulya 1917.

5. Stepun F. O politicheskom vospitanii v armii // Armiya i Flot svobodnoy Rossii. № 162. 28 iyulya 1917.

6. Stepun F. Koalitsionnoe pravitel'stvo // Armiya i Flot svobodnoy Rossii. № 165-166. 16 iyulya 1917. 